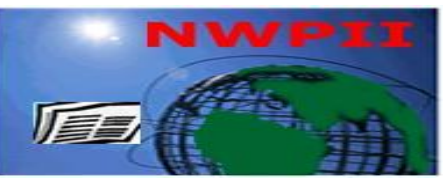

American Journal of Biomedical Sciences

ISSN: 1937-9080

nwpii.com/ajbms

\title{
Investigation of Some Biochemical Parameters in Subject with HbSC and HbSS in Saki West Local Government - a Rural Community in Nigeria
}

\author{
Mathew Folaranmi Olaniyan
}

Department of Medical Laboratory Science, Achievers University, Owo, Nigeria.

Corresponding Author

Mathew Folaranmi Olaniyan

Department of Medical Laboratory Science

Achievers University

Owo,Nigeria

GSM: +2348052248019 OR + 2347033670802

Email: olaniyanmat@yahoo.com

Received: 08 September 2016; | Revised: 20 September 2016; | Accepted: 25 September 2016

\begin{abstract}
Background: HbSS and HbSC are a group of genetic blood disorders. They are examples of sickle cell diseases.The complication of sickle cell disease could affect spleen, brain, eyes, lungs, liver, heart, kidneys, penis, joints, bones, or skin. Aim and Objective: This work was designed to measure plasma ALT, AST, Albumin,Se, $\mathrm{Zn}$ and Uric acid in HbSS and HbSC patients in Saki-West Local Government area of Oyo state-Nigeria. Materials and Methods: $\mathrm{HbSS}$ and HbSC patients in crisis and in non-crisis steady state classified into $\mathrm{HbSC}(\mathrm{n}=25)$ and $\mathrm{HbSS}(\mathrm{n}=25)$ aged 10 to 31 years were recruited as test subjects for the study. Apparently healthy $50 \mathrm{HbAA}$ volunteers classified into female $(n=25)$ and male $(n=25)$ aged $10-$ 50 years were also studied as control. Subjects residing in Saki-West for not less than 5 years were recruited as test and control subjects. Plasma Albumin, Uric acid, ALT(Alanine Transaminase), AST(Aspartate Trans aminase) were determined biochemically bt spectrophotometry.Plasma Zn (Zinc) and Se (Selenium) were measured by Atomic Absorption Spectrophotometry. Results: The result obtained showed a significantly higher mean value of plasma ALT and AST in HbSC and HbSS than HbAA with p<0.05. The result also showed a significantly lower plasma selenium mean value in HbSC and HbSS than HbAA with p<0.05 This biochemical alterations including plasma $\mathrm{Zn}$ was more in crisis than in non-crisis steady state. Conclusion and Recommendation: Decreased plasma level of Selenium and increased plasma AST and ALT were found in $\mathrm{HbSS}$ and $\mathrm{HbSC}$ patients. This biochemical alterations including plasma $\mathrm{Zn}$ was more in crisis than in non-crisis steady state.
\end{abstract}

Keywords: ALT, AST, Sickle cell, Zinc, Selenium, Albumin,Uric acid 


\section{Introduction}

Sickle cell disease (SCD) describes a group of inherited red blood cell disorders. People with SCD have abnormal hemoglobin, called hemoglobin S or sickle hemoglobin, in their red blood cells such as HbSS and HbSC. Problems in sickle cell disease typically begin around 5 to 6 months of age. A number of health problems may develop, such as attacks of pain ("sickle-cell crisis"), anemia, bacterial infections, and stroke.Long term pain may develop as people get older. The average life expectancy in the developed world is 50 years (Rees et al., 2010)

The red blood cell sickling and poor oxygen delivery can also cause organ damage. Over a lifetime, SCD can affect spleen, brain, eyes, lungs, liver, heart, kidneys, penis, joints, bones, or skin.Hemoglobin is a protein in red blood cells that carries oxygen throughout the body (Serjeant, 2010). Biochemical alterations have been associated with $\mathrm{HbSS}$ and $\mathrm{HbSC}$ (Oladipo et al., 2005). $\mathrm{HbSS}$ and $\mathrm{HbSC}$ is a hereditary disorder of hemoglobin synthesis that can affect the skeletal system owing to accelerated hematopoiesis and bone infarction (Nelson et al., 2003; Nouraie et al., 2011). The level of alkaline phosphatase indicates severity of bone damage and is a useful guide of progress in the management of bone pains in $\mathrm{HbSS}$ and $\mathrm{HbSC}$ (Afonja and Boyd., 1986; Adewoye et al., 2008). $\mathrm{HbSS}$ and $\mathrm{HbSC}$ is associated with impaired urinary potassium excretion. Many renal abnormalities have been associated with $\mathrm{HbSS}$ and HbSC (Allon, 1990). Total protein concentration is determined by the nutritional state, hepatic function, renal function, and various disease states and hydration. Contribution of bone turnover to the hyper-catabolic state observation in sickle cell anemia is unknown while a study state the increased rates of bone turnover contribute to the increased rates of protein turnover and energy expenditure observed in HbSS (Buchowski., 2001). Hepatic dysfunction is a commonly recognized complication of $\mathrm{HbSS}$ and HbSC due to multiple factors such as intrahepatic sinusoidal sickling, bilirubin gallstones, transfusion-related hepatitis infections or excess iron deposition (Schubert, 1986; Kakarala and
Lindberg, 2004; Beutler, 1999). Elevated aminotransferase levels are commonly associated with compromised hepatic integrity from various pathophysiology. In HbSS and $\mathrm{HbSC}$, aspartate transaminase (AST) is released via intravascular hemolysis (Nsiah et al 2011). Serum creatinine may be associated with renal insufficiency in sickle cell patients. When serum creatinine is elevated the disease has reached an advanced stage and lead to renal failure. Deoxygenation of sickle cell is known to increase cation permeability of sodium $\left(\mathrm{Na}^{+}\right)$, potassium $\left(\mathrm{K}^{+}\right)$ and calcium $\left(\mathrm{Ca}^{2+}\right)$ (Vitoux et al., 1989; Rhoda et al., 1990; Gibson et al., 1998). Urea, an end product of protein metabolism, is excreted by the kidney. Blood urea nitrogen directly related to protein intake and nitrogen metabolism and inversely related to the rate of excretion of urea. Urea concentration in glomerular filtrate is the same as in plasma, but its tubular re-absorption is inversely related to the rate of urine formation. Urea may play a significant role in the precipitation of sickling crisis (Vener 1977). AST:ALT (Alanine Aminotransferase) ratio may play role as a hemolytic marker, because it has an inverse association with the hemoglobin level. Whether in steady state or in crisis, provided hepatic and cardiac integrity has not been compromised, subjects with $\mathrm{HbSS}$ and $\mathrm{HbSC}$ would have higher AST levels due to the hemolytic nature of the condition (Maddrey et al., 1978). In sickle cell anemia the shortened survival of red blood cells presents the liver with an augmented load of bilirubin for hepatic clearance (Conger, 1990). Uric acid is an end product of nucleoprotein metabolism and is excreted by the kidney. An increase in serum uric acid concentration occurs with increased nucleoprotein synthesis or catabolism or decreased renal excretion. It poses a special problem for humans because of its limited solubility, particularly in the acidic environment of the distal nephron of the kidney (Diamond $e t$ al., 1979). Hyperuricemia occurs only in patients who develop altered renal tubular function with diminished urate clearance secondary to diminished urate secretion (Diamond et al., 1979). 
Zinc is an essential trace metal, which is second only to Iron. It is present in Zinc metalloenzymes e.g. carbonic anhydrase, alkaline phosphatase, R.N.A and D.N.A polymerases, thimidine kinase, carboxypeptidases and alcohol dehydrogenase. Zinc is an essential element; it is a critical cofactor for carbonic anhydrase, alkalinephosphatase, RNA and DNA polymerases, alcohol dehydrogenase, and many other physiologically important proteins. The peptidases, kinases, and phosphorylases are most sensitive to zinc depletion. Zinc is a key element required for active wound healing (Zorbas et al.,2008). Zinc depletion occurs either because it is not absorbed from the diet (excess copper or iron interfere with absorption) or it is lost after absorption. Dietary deficiency may be due to absence (parenteral nutrition) or because the zinc in the diet is bound to phytate (fiber) and not available for absorption. Excess copper and iron in the diet (eg, iron supplements) interfere with zinc uptake (Skelton et al., 2006; Burri et al., 2008).

Selenium is an essential element. It is a cofactor required to maintain activity of glutathione peroxidase (GSH-Px), an enzyme that catalyzes the degradation of organic hydroperoxides. The absence of selenium correlates with loss of GSH-Px activity and is associated with damage to cell membranes due to accumulation of free radicals. The normal daily dietary intake of selenium is 0.01 to 0.04 parts per million (ppm), which is similar to the typical content of soil $(0.05 \mathrm{ppm})$ and sea water $(0.09$ ppm) (Stadtman and Thressa 2002). In humans, cardiac muscle is the most susceptible to selenium deficiency. With cell membrane damage, normal cells are replaced by fibroblasts. This condition is known as cardiomyopathy and is characterized by an enlarged heart whose muscle is largely replaced by fibrous tissue (Aringer and Graessler, 2008). Selenium is not classified as a human teratogen. Glutathione Peroxidase to test your selenium levels - low selenium levels can cause low immunity, constant fatigue and reproductive problems (Kaneko, 1999).

\section{Aim and Objective}

This work was designed to determine the plasma level of ALT, AST, Zn,Se, Albumin and Uric acid in patients with $\mathrm{HbSC}$ and $\mathrm{HbSS}$ in crisis and in non- crisis steady state using HbAA individuals as control subject in a rural community.

\section{Materials and Methods}

\subsection{Materials}

\subsubsection{Study area}

Saki -West local government area which is located at the Nothern-part of Oyo state. It shares border with Benin republic, Kwara State, SakiEast and ATISBO local government areas of Oyo State-Nigeria.

\subsubsection{Study population and criteria}

$\mathrm{HbSS}$ and HbSC patients in crisis and in non-crisis steady state classified into $\mathrm{HbSC}$ $(n=25)$ and $\operatorname{HbSS}(n=25)$ aged 10 to 31 years attending Baptist Medical Centre, Saki - Nigeria were recruited as test subjects for the study. Apparently healthy $50 \mathrm{HbAA}$ volunteers classified into female $(n=25)$ and male $(n=25)$ aged $10-50$ years were also studied as control.

Five (5) mililitres of venous blood was obtained into each of the subjects into Lithium heparinized tube for haemoglobin electrophoresis and estimation of ALT,AST, Albumin, Selenium, Zinc and Uric acid.

Only HbSS and HbSC in crisis and noncrisis steady state were recruited.

Subjects with evidence of liver disease were excluded.

Subjects who are alcoholics and cigarette smokers were excluded.

\subsection{Methods}

\subsubsection{BromoCresolGreen method}

Serum albumin estimation was carried out on all the volunteers [test and control] by BromoCresolGreen method.

Principle of the test: Bromocresol green is an indicator which is yellow between $\mathrm{P}^{\mathrm{H}} 3.5-4.2$. 
When it binds to albumin the colour of the indicator changes from yellow to blue - green. The absorbance of the colour produced is measured in a colorimeter using an orange filter in a spectrophotometer at $632 \mathrm{~nm}$ wavelengths.

\subsubsection{Determination of serum levels of $\mathrm{Zn}$ and} Se.

Serum levels of these elements were determined with flame atomic absorption spectrophotometer (AAS) using a direct method described by Kaneko (Kaneko, 1999).

Principle of the test: the method is based on the principle that atoms of the element when aspirated into AAS vaporized and absorbed light of the same wavelength as emitted by the element when in the excited state.

\section{Procedure:}

1. Atomic Absorption Spectrophotometric measurement of the micronutrients concentrations were performed on a BECK 200 atomic absorption spectrophotometer.

2. Flame was ignited and lamp switched on.

3. The instrument was allowed to warm up while aspirating de-ionized water into the flame and then adjusted to zero absorbance.

4 Standards of corresponding analyte was aspirated to standardize the machine. This standardization was repeated periodically to asses any drift of sensitivity.

5. The smples kept frozen were thawed and 1:25 dilution was made for $\mathrm{Mg}$ while samples for other micronutrients under investigation were aspirated directly into AAS for analysis.

6 . The results of the assays were displayed digitally on the instrument.

Calculation: Meter reading multiply by dilution factor multiplies by PPM of standard.

\subsubsection{Aspartate aminotransferase}

Aspartate aminotransferase (AST/SGOT) was determined in all the sera of the volunteers spectrophotometrically by using the reagent kit of; Cromatest Linear Chemicals S.L, Joaquim Costa,18， $2^{\mathrm{a}} \quad$ Planta ,08390 MontgatBarcelona(Spain). http://www.linear.es

Priciple of test: Aspatate aminotransferase (AST/SGOT) catalyses the transfer of the amino group from aspartate to oxoglutarate with the formation of glutamate and oxaloacetate.The latter is reduced to malate by malate dehydrogenase (MDH) in the presence of reduced nicotinamide adenine dinucleotide (NADH). The reaction is monitored kinetically at $340 \mathrm{~nm}$ by the rate of decrease in absorbance resulting from the oxidation of $\mathrm{NADH}$ to $\mathrm{NAD}^{+}$, proportional to the activity of AST present in the sample.

L-aspartate + 2-oxoglutarate AST/SGOT Lglutamate + oxaloacetate

Oxaloacetate $+\mathrm{NADH}+\mathrm{H}^{+} \quad \mathrm{MDH} \quad \mathrm{L}-$ malate $+\mathrm{NAD}^{+}$

\subsubsection{Alanine aminotransferase}

Alanine aminotransferase (ALT/SGPT) was determined in all the sera of the volunteers spectrophotometrically by using the reagent kit of; Cromatest Linear Chemicals S.L, Joaquim Costa, 18, $\quad 2^{\text {a }}$ Planta, $08390 \quad$ MontgatBarcelona(Spain). http://www.linear.es

Priciple of test: Alanine aminotransferase (ALT/SGPT) reversibly transfers the amino group from alanine to alpha - ketoglutarate, forming pyruvate and glutarmate. The rate of formation of pyruvate is determined by coupling the ALT reaction with that of lactate dehydrogenase (LDH), which converts the pyruvate to lactate; the decrease in absorbance at $340 \mathrm{~nm}$ is measured as $\mathrm{NADH}$ is oxidized to $\mathrm{NAD}^{+}$.

\subsubsection{Uric acid}

Uric acid was determined using RANDOX reagent kit.

\subsubsection{Haemoglobin electrophoresis}

Haemoglobin electrophoresis was carried on each of the subjects as described by Chessbrough (Cheesbrough, 2002).

\subsection{Ethical Consideration}

The proposal of this work was submitted to the Research and Ethical committee of Baptist Medical Centre, Saki-Nigeria for consideration. The proposal was approved before the commencement of this work. 


\subsection{Method of Data analysis}

The raw data was subjected to statistical analysis using SPSS 18.0 to determine the mean, standard deviation, probability, ' $t$ ' test value and level of significance at 0.05 .

\section{Results}

The results obtained showed that there was no significant difference in the mean values of ALT, AST, albumin, Zn, Se and Uric acid obtained in $\mathrm{HbSC}$ and HbSS with $\mathrm{p}>0.05$ (Tables 1 \&4; figure 1). However, there was a significantly higher mean value of plasma ALT and AST in HbSC and HbSS than HbAA with $\mathrm{p}<0.05$ (Tables $1 \& 4$ ). The result also showed a significantly lower plasma selenium mean value in $\mathrm{HbSC}$ and $\mathrm{HbSS}$ than $\mathrm{HbAA}$ with $p<0.05$ (Tables $1 \& 4$ ). There was no significant difference in the mean values of plasma albumin and uric acid in $\mathrm{HbSS}$ and $\mathrm{HbSC}$ in crisis compared to when they were in non-crisis steady date $(p>0.05)$ (Tables 1,2,3; figures 1,2).This difference was also found in the plasma value of ALT and Se in HbSS patient in crisis and in noncrisis steady state. There was a significantly higher plasma value of ALT, AST and a lower plasma $\mathrm{Zn}$ and $\mathrm{Se}$ in HbSS patients in crisis than in non-crisis steady state with $\mathrm{p}<0.05$. There was a significantly higher plasma value of AST and a lower plasma $\mathrm{Zn}$ in HbSS patients in crisis than in non-crisis steady state with $\mathrm{p}<0.05$ (Tables $1,2,3$; figures 1,2$)$.

Table 1. The mean and standard deviation of the values of ALT,AST, albumin, Zn, Se and Uric acid obtained in HbSC, HbSS in non-crisis steady state and HbAA subjects.

\begin{tabular}{|l|c|c|c|}
\hline & $\operatorname{HbSC}(\mathrm{n}=25)$ & $\operatorname{HbSS}(\mathrm{n}=25)$ & $\operatorname{HbAA}(\mathrm{n}=50)$ \\
\hline ALT(U/L) & $64 \pm 5.0$ & $68 \pm 5.0$ & $17 \pm 3.0$ \\
\hline AST(U/L) & $51 \pm 4.0$ & $58 \pm 2$ & $10 \pm 2 ; 0$ \\
\hline Albumin(g/dl) & $3.0 \pm 0.4$ & $2.8 \pm 0.5$ & $4.1 \pm 0.6$ \\
\hline $\mathrm{Zn}(\mathrm{mcg} / \mathrm{ml})$ & $0.41 \pm 0.01$ & $0.38 \pm 0.01$ & $0.9 \pm 0.03$ \\
\hline Se( ng/ml $)$ & $58 \pm 3.0$ & $55 \pm 4.0$ & $86 \pm 3.0$ \\
\hline Uric acid(mg/dl) & $3.0 \pm 0.4$ & $2.7 \pm 0.4$ & $3.9 \pm 0.5$ \\
\hline
\end{tabular}

Table 2. The mean and standard deviation of the values of ALT,AST,albumin, Zn, Se and Uric acid obtained in HbSC, $\mathrm{HbSS}$ in crisis and HbAA subjects.

\begin{tabular}{|l|c|c|c|}
\hline & HbSC(n=25) & HbSS(n=25) & HbAA(n=50) \\
\hline ALT(U/L) & $69 \pm 2.0$ & $86 \pm 3.0$ & $17 \pm 3.0$ \\
\hline AST(U/L) & $68 \pm 3.0$ & $79 \pm 2.0$ & $10 \pm 2 ; 0$ \\
\hline Albumin(g/dl) & $3.2 \pm 0.3$ & $3.0 \pm 0.3$ & $4.1 \pm 0.6$ \\
\hline Zn(mcg/ml) & $0.3 \pm 0.01$ & $0.29 \pm 0.02$ & $0.9 \pm 0.03$ \\
\hline Se( ng/ml) & $51 \pm 2.0$ & $49 \pm 3.0$ & $86 \pm 3.0$ \\
\hline Uric acid(mg/dl) & $3.9 \pm 0.3$ & $4.5 \pm 0.2$ & $3.9 \pm 0.5$ \\
\hline
\end{tabular}


Table3. Comparative analysis of the biochemical alterations in $\mathrm{HbSS}$ and $\mathrm{HbSC}$ in crisis and in non-crisis steady state.

\begin{tabular}{|l|c|c|c|c|c|c|c|}
\hline & & ALT & AST & Albumin & Zn & Se & Uric acid \\
\hline \multirow{2}{*}{$\begin{array}{l}\text { HbSS in } \\
\text { crisis and in } \\
\text { non-crisis } \\
\text { steady state }\end{array}$} & ' $\mathrm{t}$ ' & 3.09 & 7.43 & 0.343. & -4.03 & -3.2 & 1.88 \\
\cline { 2 - 8 } & comment & $\mathrm{p}<0.05^{* *}$ & $\mathrm{p}<0.05^{* *}$ & $\mathrm{p}>0.05^{*}$ & $\mathrm{p}<0.05^{* *}$ & $\mathrm{p}<0.05^{* *}$ & $\mathrm{p}>0.05^{*}$ \\
\hline \multirow{2}{*}{$\begin{array}{l}\text { HbSS in } \\
\text { crisis and in } \\
\text { non-crisis } \\
\text { steady state }\end{array}$} & ' $\mathrm{t}$ ' & 0.93 & 3.4 & 0.99 & -7.78 & -1.94. & 1.8. \\
\cline { 2 - 8 } & comment & $\mathrm{p}>0.05^{*}$ & $\mathrm{p}<0.05^{* *}$ & $\mathrm{p}>0.05^{*}$ & $\mathrm{p}<0.05^{* *}$ & $\mathrm{p}>0.05^{*}$ & $\mathrm{p}>0.05^{*}$ \\
\hline
\end{tabular}

Table 4. Shows the level of significance of the difference in the mean value of the biochemical parameters obtained in $\mathrm{HbSS}, \mathrm{HbSC}$ and HbAA.

\begin{tabular}{|c|c|c|c|c|}
\hline & & $\mathrm{HbSC} / \mathrm{HbSS}$ & $\mathrm{HbSC} / \mathrm{HbAA}$ & $\mathrm{HbSS} / \mathrm{HbAA}$ \\
\hline \multirow{2}{*}{$\operatorname{ALT}(\mathrm{U} / \mathrm{L})$} & 't' value & -0.56569 & -3.48526 & 8.74643 \\
\hline & 'p' value & $0.314305^{*}$ & $0.036689 * *$ & $0.006411^{* *}$ \\
\hline \multirow{2}{*}{ AST(U/L) } & ' $\mathrm{t}$ ' value & -1.56525 & 9.16788 & 16.97056 \\
\hline & 'p' value & $0.129001 *$ & $0.005845^{* *}$ & $0.001727 * *$ \\
\hline \multirow{2}{*}{$\operatorname{Albumin}(\mathrm{g} / \mathrm{dl})$} & 't' value & 0.31235 & -1.52543 & -1.66448 \\
\hline & 'p' value & $0.392167 *$ & $0.133333^{*}$ & $0.118963^{*}$ \\
\hline \multirow{2}{*}{$\mathrm{Zn}(\mathrm{mcg} / \mathrm{ml})$} & 't' value & 2.12132 & -1.63243 & -1.73237 \\
\hline & 'p' value & $0.083975^{*}$ & $0.122092 *$ & $.112673 *$ \\
\hline \multirow{2}{*}{$\mathrm{Se}(\mathrm{ng} / \mathrm{ml})$} & 't' value & 0.6 & -6.59966 & -6.2 \\
\hline & 'p' value & $0.304717 *$ & $0.011099 * *$ & $0.012521 * *$ \\
\hline \multirow{2}{*}{ Uric $\operatorname{acid}(\mathrm{mg} / \mathrm{dl})$} & 't' value & 0.53033 & -1.40556 & -1.87409 \\
\hline & 'p' value & $0.324438 *$ & $0.147533^{*}$ & $0.100886^{*}$ \\
\hline
\end{tabular}




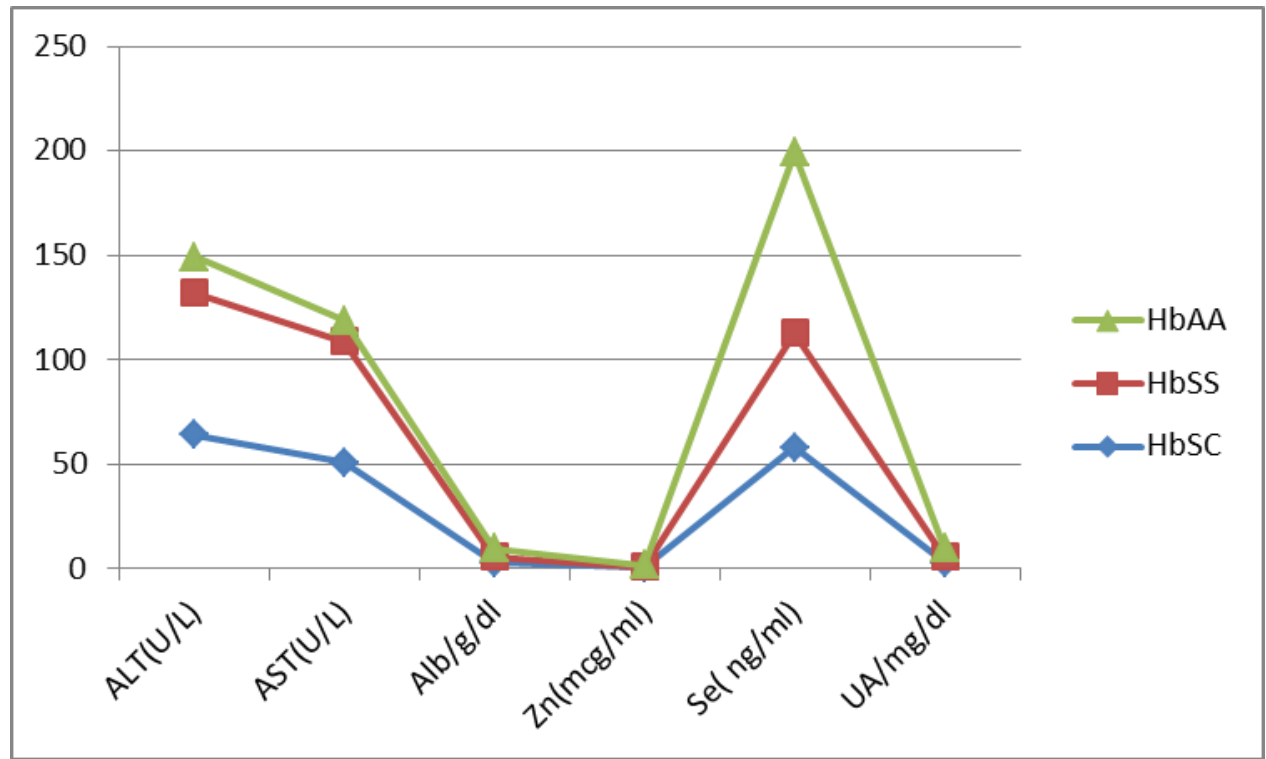

Figure 1. The mean and standard deviation of the values of ALT,AST,albumin, Zn, Se and Uric acid obtained in $\mathrm{HbSC}, \mathrm{HbSS}$ in non-crisis steady state and HbAA subjects.

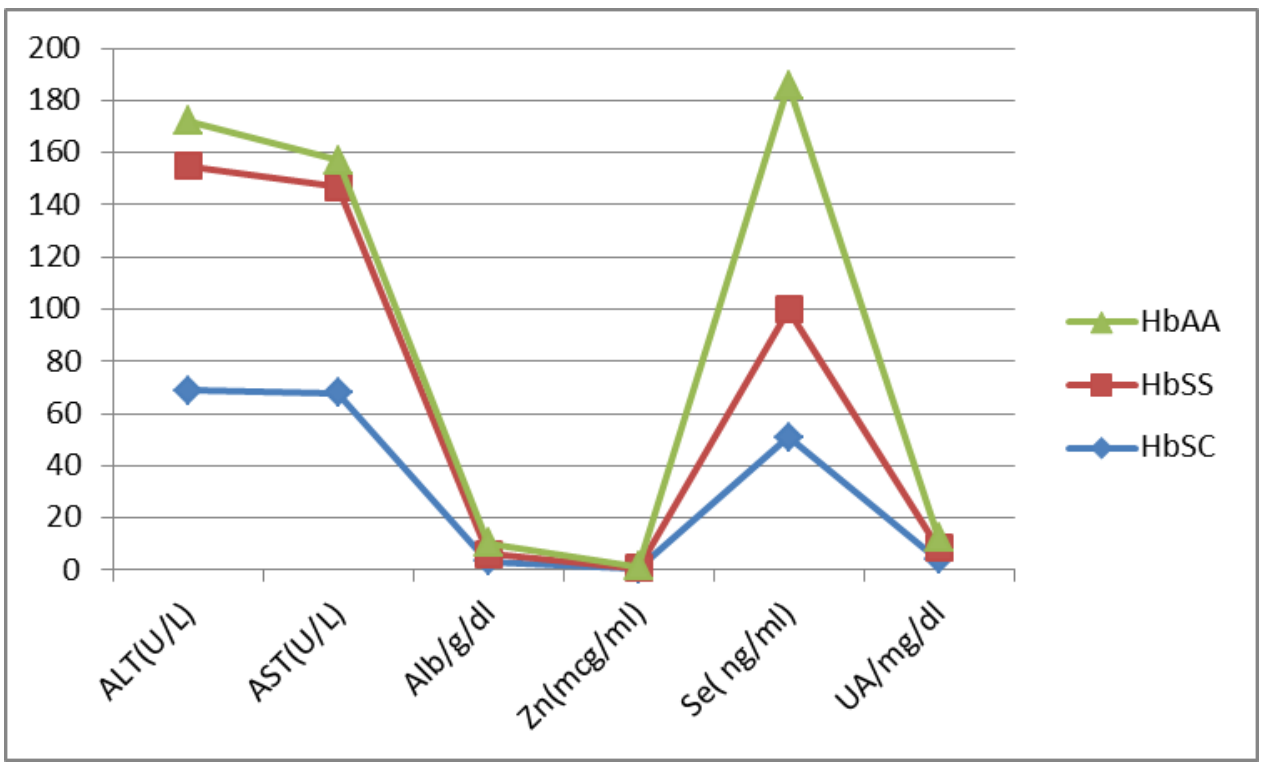

Figure 2. The mean and standard deviation of the values of ALT,AST,albumin, Zn, Se and Uric acid obtained in $\mathrm{HbSC}, \mathrm{HbSS}$ in crisis and HbAA subjects.

\section{Discussion}

Significantly higher mean value of plasma ALT and AST found in HbSC and HbSS than $\mathrm{HbAA}$ is consistent with the report of Chuku et al., (Chuku et al., 2012). ALT is found in the liver and could be released to the blood circulation when the liver is injured or disturbed.
This will therefore result into plasma elevation of ALT. This finding could also be associated with the fact that the red blood cell sickling and poor oxygen delivery can cause organ damage. Over a lifetime, SCD can affect spleen, brain, eyes, lungs, liver, heart, kidneys, penis, joints, bones, or skin (Banerjee et al., 2001) AST is found in the liver as well as other tissue including red 
blood cells. Sickle cell disease is characterized by haemolysis and liver is also involved in the pathophysiology. These could cause leakage of AST into the blood circulation. Patients with SCD commonly present with one of several acute hepatic syndromes that manifest clinically as fever, right upper quadrant pain, and jaundice. Frequent haemolytic crisis leading to anaemia and shorter life span of sickle cells than normal could be contributory to increased AST leaked into the plasma as a result of massive red blood cell damage (Diggs and Bell, 1965. Patients with acute sickle hepatic cri- sis typically present with in- creased serum AST and ALT levels up to 300 $\mathrm{U} / \mathrm{L}$ and an increased serum bilirubin level up to 15 mg/dL. (Sheehy , 1977; Schubert , 1986; Susan et al., 2009).

Significantly lower mean value of plasma selenium was found in $\mathrm{HbSC}$ and $\mathrm{HbSS}$ than HbAA. One of the hallmarks of both sickle cell disease (SCD) and thalassemia major (TM) is accelerated oxidative damage. Decreased antioxidant levels and increased oxidant stress biomarkers are found in both diseases (Susan et al., 2009).. Susan et al., 2009 reported that 40$75 \%$ of the patients were deficient in A, C, D and selenium and $28-38 \%$ of the patients had low levels of B vitamins and folate which is consistent with the findings of this study. Selenium is an antioxidant that prevents cellular damage which is common in sickle cell disease that may warrant excessive use of Selenium leading to decresed concentration as found in this study. Mona et al., 2015 also found a depleted antioxidants level in the studied group of Egyptian children with TM and SCD relative to healthy controls.

There was a significantly higher plasma value of AST and a lower plasma $\mathrm{Zn}$ in $\mathrm{HbSS}$ patients in crisis than in non-crisis steady state. There was also a significantly higher plasma value of ALT, AST and a lower plasma $\mathrm{Zn}$ and Se in HbSS patients in crisis than in non-crisis steady state. This finding is consistent with the report of Oladipo et al., 2005 that associated biochemical alterations with $\mathrm{HbSS}$ and $\mathrm{HbSC}$ which is more exacerbated in sickle cell crisis. Elevated aminotransferase levels are commonly associated with compromised hepatic integrity from various pathophysiology (Banerjee et al., 2001). Elevated AST and ALT in this study could be due to the liver involvement in the pathophysiology of sickle cell diseases/crisis due to the fact that AST and ALT are liver enzymes that could leak to the plasma in hepatic disorder This finding is also consistent with the report of Nsiah et al.,2011 that in HbSS and HbSC, aspartate transaminase (AST) is released via intravascular hemolysis. In addition there used to be massive haemolysis in sickle cell crisis making the liver to metabolise RBC excessively which may bring about liver disorder hence the biochemical alterations in the value AST and ALT (Banerjee et al., 2001; Nsiah et al.,2011)

$\mathrm{Zn}$ and Se are antioxidants and acute phase metals. In crisis they are more utilized to prevent or scavenge oxidation which could be responsible for the decreased concentration in $\mathrm{HbSS}$ and HbSC patients crisis compared with those in non-crisis steady state. As acute phase metals they have their level decreased on infection and inflammation which was found in this study (Banerjee et al., 2001; Mona et al., 2015).

\section{Conclusion}

The biochemical profile of sickle cell patients has been investigated to reveal Significantly lower mean value of plasma selenium in $\mathrm{HbSC}$ and $\mathrm{HbSS}$ than $\mathrm{HbAA}$ and a Significantly higher mean value of plasma ALT and AST in HbSC and HbSS than HbAA. There was an increase in the plasma activities of ALT and AST and a decrese in the plasma value of $\mathrm{Zn}$ and $\mathrm{Se}$ in $\mathrm{HbSS}$ and $\mathrm{HbSC}$ in crisis than in noncrisis steady state.

\section{Recommendation}

It is therefore suggested that the routine Laboratory investigation of $\mathrm{HbSS}$ and $\mathrm{HbSC}$ should include measurement of AST,ALT, Zn and $\mathrm{Se}$ in crisis and in non-crisis steady state for effective management. 


\section{References}

1. Adewoye AH, Chen TC, Ma Q, McMahon L, Mathieu J, Malabanan A, Steinberg MH, Holick MF, 2008. Sickle cell bone disease: response to vitamin D and calcium. Am J Hematol. 83(4):271-274. doi: 10.1002/ajh.21085.

2. Afonja OA, Boyd AE 1986. Plasma alkaline phosphatase and osteoblastic activity in sickle cell anaemia. J Trop Pediatr. 32(3):115-116.

3. Allon M, 1990. Renal abnormalities in sickle cell disease. Arch Intern Med. 150(3):501504.

doi:

10.1001/archinte.1990.00390150015003.

4. Aringer M, J, 2008."Understanding deficient elimination of uric acid". Lancet. 372 (9654): 1929-30. doi:10.1016/S01406736(08)61344-6. PMID 18834627.

5. Banerjee S, Owen C, Chopra S, 2001. Sickle cell hepatopathy. Hepatology. 33:1021-28.

6. Beutler E, 1999. The sickle cell diseases and related disorders. In: Beutler E, Lichtman MA, Coller BS, Kipps TJ, Seligsohn U, editors. Williams hematology. New York: McGrawHill; 4: pp. 581-605.

7. Buchowski MS, la Fuente FA, Flakoll PJ, Chen KY, Turner EA, 2001. Increased bone turnover is associated with protein and energy metabolism in adolescents with sickle cell anemia. Am J Physiol Endocrinol Metab. 280:E518-E527.

8. Burri J, Haldiman M, Dudler V, 2008: Selenium status of the Swiss population: assessment and change over a decade. J Trace Elem Med Biol. 22(2):112-119

9. Cheesbrough Monica, 2002. District Laboratory Practice in Tropical Countries Part 2. Cambridge University press, U.K Cambridge Low Price edition, Pps 246-266, 332-340.

10. Chuku, L.C. , Uwakwe, A.A. and Chinaka, N.C, 2012. Liver Enzymes in Normal And Sickle Cell Subjects. Journal of Natural Sciences Research www.iiste.org ISSN 2224-3186 (Paper) ISSN 2225-0921 (Online) Vol.2, No.7,
11. Conger JD, 1990. Acute uric acid nephropathy. Med Clin N Am.74(4):859871.

12. Diamond HS, Meisel AD, Holden D, 1979. The natural history of urate overproduction in sickle cell anemia. Ann Intern Med. 90(5):752-757.

13. Diggs LW, Bell A, 1965. Intraerythrocytic hemoglobin crystals in sickle cellhemoglobin C disease. Blood. 25:218-223. doi:10.1007/0-306-47466-2_267. ISBN 0306-46378-4. doi:10.3324/haematol.2011.042499.

14. Gibson JS, Speake PF, Ellory JC, 1998. Differential oxygen sensitive of the $\mathrm{K}^{+}$and $\mathrm{Cl}^{-}$co transporter in normal and sickle human red blood cells. J Physiol. 511(1):225-233. doi: $10.1111 / \mathrm{j} .1469-$ 7793.1998.225bi.x

15. Kakarala S, Lindberg M 2004. Safety of liver biopsy in acute sickle hepatic crisis. Conn Med. 68(5):277-279.

16. Kaneko J. J, 1999. Clinical Biochemistry of Animal.4th edition (Kaneko J.J,Editor) Academic Press Inc; New York. 5:pp 932.:

17. Maddrey WC, Cukier JO, Maglalang AC, Boitnott JK, Odell GB, 1978. Hepatic bilirubin UDP-glucuronyltransferase in patients with sickle cell anemia. Gastroenterology. 74(2 Pt 1):193-195.

18. Mona M. Hamdya, Dalia S. Mosallama, Alaa M. Jamala, Walaa A. Rabieb, 2015. Selenium and Vitamin $\mathrm{E}$ as antioxidants in chronic hemolytic anemia: Are they deficient? A case-control study in a group of Egyptian children. Journal of Advanced Research. 6(6); 1071-1077

19. Nelson DA, Rizvi S, Bhattacharyya T, Ortega J, Lachant N, Swerdlow P, 2003. Trabecular and integral bone density in adults with sickle cell disease. J Clin Densitom. 6(2):125-129. doi: 10.1385/JCD:6:2:125.

20. Nouraie M, Cheng K, Niu X, Moore-King E, Fadojutimi-Akinsi MF, Minniti CP, et al., 2011. Predictors of osteoclast activity in sickle cell disease patients. Haematologica. 96:42-49.

21. Nsiah K, Dzogbefia VP, Ansong D, Osei Akoto A, Boateng H, Ocloo D, 2011. Pattern 
of AST and ALT changes in relation to hemolysis in sickle cell disease. Clin Med Insight Blood Disord.4:1-9. doi: 10.4137/CMBD.S3969.

22. Oladipo O, Temiye EO, Ezeaka VC, Obomanu P, 2005. Serum, magnesium, phosphate and calcium in Nigerian children with sickle cell disease. West Afr J Med. 24(2):120-123.

23. Rees, DC; Williams, TN; Gladwin, MT, 2010. "Sickle-cell disease.". Lancet (London, England) . 376 (9757): 2018-31. PMID 21131035.

24. Rhoda MD, Apovo M, Beuzard Y, Giraud F, 1990. $\mathrm{Ca}^{2+}$ permeability in de oxygenated sickle cells. Blood.75(12):2453-2458.

25. Schubert TT, 1986. Hepatobiliary system in sickle cell disease. Gastroenterology. 90(6):2013-2021.

26. Schubert TT, 1986. Hepatobiliary system in sickle cell disease. Gastroenterology. 90:2013-2021

27. Serjeant GR, 2010 ."One hundred years of sickle cell disease. British journal of haematology. $\quad 151 \quad(5): \quad 425-9$. doi:10.1111/j.1365-2141.2010.08419.x.

28. Sheehy TW, 1977. Sickle cell hepatopathy. South Med J. 70:533-538.
29. Skelton JA, Havens PL, Werlin SL, 2006. Nutrient deficiencies in tube-fed children. Clin Pediatr 45(1):37-41

30. Stadtman, Thressa C, 2002. . "Some Functions of the Essential Trace Element, Selenium". Trace Elements in Man and Animals.10: 831-836.

31. Susan Claster, John C. Wood,2,3 Leila Noetzli, Susan M. Carson, Thomas C. Hofstra, Rachna Khanna, 1 and Thomas D. Coate, 2009. Nutritional deficiencies in iron overloaded patients with hemoglobinopathies. Am J Hematol. 84(6): 344-348. doi: 10.1002/ajh.21416

32. Vener KJ, 1977. Urea and sickle cell anemia. J Theor Biol. 66(3):457-460. doi: 10.1016/0022-5193(77)90295-8.

33. Vitoux D, Olivieri O, Garay RP, Cragoe EJ, Jr, Galacterous F, Bevizard Y, 1989. Inhibition of $\mathrm{K}^{+}$efflux and dehydration of sickle cells by [(dihydroindenyl)oxy] alkanoic acid: an inhibitor of the $\mathrm{K}^{+}-\mathrm{Cl}^{-}$co transport system. Proc Natl Acad Sci USA .86(11):4273-4276. doi: 10.1073/pnas.86.11.4273.

34. Zorbas YG, Kakuris KK, Neofitov IA, Afoninos NI, 2008: Zinc utilization in zincsupplemented and -unsupplemented healthy subjects during and after prolonged hypokinesis. Tr Elem Electro. 25:60-68. 